\title{
PARTICIPATORY PROCESS OF HEALTH PROMOTION AT SCHOOL
}

\author{
Lucas Dias Soares Machado', José Lucas Souza Ramos'1, \\ Maria de Fátima Antero Sousa Machado ${ }^{1}$, Jennifer Yohanna Ferreira de Lima Antão2, \\ Shayane Bezerra dos Santos' ${ }^{1}$ Mirna Neyara Alexandre de Sá Barreto Marinho', \\ Gislaine Loiola Saraiva Freitas ${ }^{3}$, Italla Maria Pinheiro Bezerra ${ }^{2,3,4}$
}

\begin{abstract}
Introduction: it is known that adolescence is a period of constant biopsychosocial changes. Based on this premise, it is understood that this population should be included as a priority in health systems, seeking their effective participation through strategies associated with health promotion. Objective: To analyse the participatory process of adolescents in health promotion activities from the perspective of the Bambu Method. Methods: this is a qualitative exploratory study, carried out in two schools located in Crato, Ceará, Brazil. Pupils are from 10 to 19 years old. The study was based on the Bambu Method, which is a means to boost the prospects of the group. It was done by observation of the participant, the environment, the verbal and non-verbal expressions of adolescents and a diary where relevant information was recorded. The organization of data occurred through the content analysis technique proposed by Bardin. Results: it was observed that the opportunity to express themselves with the host led young people to feel more at ease among others and induced the formation of a bond. The participatory process for adolescents was perceived as a process of facing reality and associated with learning, the stimulus for personal development, through the initiative of action, attitude and self-esteem. Conclusion: the Bambu Method proved to be a relevant framework to guide health education activities with groups of adolescents, allowing the development of activities suitable to the needs of the participants.
\end{abstract}

Key words: adolescents, health promotion, health education school, participation.

\section{INTRODUCTION}

Living and health conditions in Brazil have shown constant improvements, reflecting positive development in social, political and economic environments. These developments are linked to the advances of the Sistema Único de Saúde (Unified Health System/SUS) and completion of its principles, such as equity, universality and completeness.

The SUS principles are oriented to have satisfactory health assistance, but, still in an incomplete way, the individuals become passive subjects of the necessary care for their development. In this context, health promotion appears as a process of empowerment of the community to act on the improvement of their life and health qualities, including greater participation in the control of this process ${ }^{1}$. Therefore, they must work on various aspects of life in order to promote health and to include all individuals.

The adolescent stage of development is known for its complexity and the transformations experienced in biological, psychological, social and cultural features, in addition to several vulnerabilities, and positive aspects such as the ability to communicate and exchange information, creativity and the free spirit.

With the understanding that health promotion is based on democratization of information and it is the joint work of the whole of society to overcome the problems, we search for a contribution from the population, proposing the connection of interests, attitudes, individuals and disciplines, to defend and improve health conditions, especially for the most vulnerable groups, such as adolescents, emphasizing the relevance of working on both the potentialities and the vulnerabilities.

\footnotetext{
1 Universidade Regional do Cariri - URCA.

2 Faculdade de Medicina do ABC - Santo André - SP.

3 Faculdade de Juazeiro do Norte -FJN.

4 Escola de Artes, Ciências e Universidade Humanidades - Universidade de São Paulo/USP.

Corresponding author: Lucas Dias Soares Machado. E-mail: Iucasdsmachado@hotmail.com
}

Suggested citation: Machado LDS, Ramos JLS, Machado MFAS, Antão JYFL, Santos SB, Bezerra IMP et al. Participatory process of health promotion at school. Journal of Human Growth and Development. 25(3): 357-363. Doi: http://dx.doi.org/10.7322/jhgd.90637 Manuscript submitted Oct 22 2014, accepted for publication Dec 192014. 
So, proposals that lead to real changes in individuals, in groups, governments and in society are needed, focusing on actions that go beyond the punctual and biomedical assistance, in order to achieve a situation in which at least the minimum conditions required for survival with dignity are ensured for the population ${ }^{2}$.

Buss $^{3}$ states that for the development of skills and personal attitudes favourable to health in all stages of life the dissemination of information on health education is essential ${ }^{3}$.

Health education is a process that, by making use of communication, is seeking to empower people to make choices about their own health, arousing the critical consciousness, recognizing the factors that influence health and encouraging them to do something to change the status quo ${ }^{4}$.

It is necessary then that health education activities are directed towards the population and that participatory methodologies are adopted, in order to involve the members in the sharing of experience, generating a positive experience.

In this sense, it is necessary that matters pertaining to adolescents' health are worked on beyond the walls of health services such as hospitals and basic units. We should consider that this crowd focuses on other sites, like school, a suitable location for the development of adolescent health, where it can be emphasized across disciplines and projects offered by the institution which complement the actions of health promotion ${ }^{5}$.

Thus, the objective of this study is to analyse the participatory process of health-promoting activities in adolescents' lives.

\section{METHODS}

This is an exploratory study with a qualitative approach conducted in the municipality of Crato, State of Ceará, Brazil, in two schools as follows: a public education high school net and a municipal elementary school, both in the same territory, selected intentionally.

We selected the scenarios based on the Bambu Method, selected by the researchers of this study. This method was created by the Núcleo de Saúde Pública e Desenvolvimento Social of the Universidade Federal do Pernambuco (UFPE) ${ }^{6}$.

It is a means to boost the potential of the group, aimed at its strengthening and transformation. The instrument is used to give life to the possibilities of the group for the good, highlighting the power of the group through the creativity and talent of each person ${ }^{6}$.

The method divides the actions in distinct and complementary moments, to meet: $1^{\text {st }}$ seeding Bambu; $2^{\text {nd }}$ starting the conversation; $3^{\text {rd }}$ introducing the project; $4^{\text {th }}$ identifying the potential of the community; $5^{\text {th }}$ wishing and creating; $6^{\text {th }}$ working together and developing a range of priorities; $7^{\text {th }}$ preparing the statement of priorities; $8^{\text {th }}$ planning activities and, finally, $9^{\text {th }}$ workshop evaluation ${ }^{6}$.

For data collection, which took place in the months of April and May of 2013, a group was formed with a total of 12 adolescents, students of both schools. The group formation was in accordance with the method adopted, the Bambu Method, which suggests the formation of a group with a composition of 8 to 15 members.

Seven meetings were held at a place, time and day prearrengedthe adolescents, according to their availability, in order to increase the membership at these meetings.

The instruments used were observation of the participant, environment, verbal and non-verbal expressions and a field journal, where the researcher recorded the pertinent information.

The data were organized according to the technique of content analysis proposed by Bardin?. After organization, data were analysed according to the theoretical framework and existing literature on participation, adolescents, health education and health promotion.

The study followed the ethical and legal principles for research involving human beings, guaranteeing autonomy, no malfeasance, beneficence and justice, among others, in accordance with resolution 466/12 National Health Council, and approved after examination by the Ethics and Research Committee of the Regional University of Cariri (URCA/CEP) with the opinion paragraph 285,438 of 5/27/2013.

\section{RESULTS}

The organization of the group, as proposed in each step of the Bambu method, is shown in Figure 1. In this organization, 12 adolescents composed the group (two male and ten female),

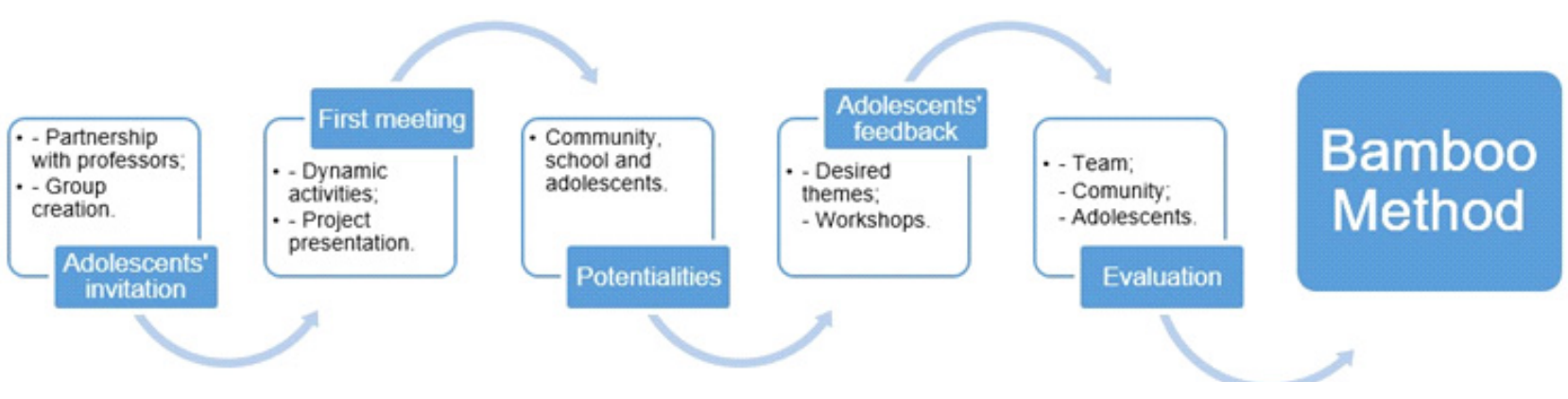

Figure 1: Bambu Method steps: promoting adolescents' participation 
students of both participant schools, with a minimum age of 12 years and a maximum of 19 years, this being the age group included in the age description adopted by the Ministry of Health ${ }^{8}$, which understands that the age of adolescence ranges from 10 to 19 years old.

As for education, two were students in the second year of high school, three in the seventh grade of elementary school, three in the eighth grade of elementary school and four students in the ninth year of elementary school. It is noteworthy that the basic education in Brazil is comprised of early childhood education, elementary education, with a minimum duration of nine years, and high school, with a minimum of three years ${ }^{9}$.

From the methodological orientation of analysis, were identified categories: Needs: ways to follow; Promotion of participation by the host and participation as a tool for social empowerment, as described in Table 1.

Table 1: Analytic features of the study representation. Crato, Ceará, Brazil. 2013

\section{Participation promotion by host}

- Hosting by dinamic activities;

- Theme presentaton by an infomal appoch;

- Educative games;

- Adolescens feedback.

\begin{tabular}{l}
$\begin{array}{r}\text { Participation as a social } \\
\text { empowerment }\end{array}$ \\
- Adolescent membership \\
- Continuous participation; \\
- Self-esteen; \\
- Secuity; \\
\hline
\end{tabular}

The reception, when noticed satisfactorily by who is hosted, can be used to expand the intent of actions and the number of members of these participants. To feel welcomed the individual tends to share the experience with someone close by multiplying the action and contributing to the accession of new members. This fact proves the words of Adolescent-09 "I came because they called me! My friends called me."

So, the first time a dynamic was performed with the aim of generating relaxation, interaction between the participants and an apprenticeship at the end, usually associated with the importance of teamwork.

During the dynamics, the relaxation was perceived by laughter and the manifestations of the adolescents, as well as dialogue between them. The interaction between the members of the group allowed dynamic objectives to be achieved through teamwork. "We learn to relate to people," said Adolescent-03.

The second time was dedicated to the explanation of the theme, which was way through dialogue, debating the topic with all members, challenging situations, clarifying doubts that have arisen and having as slide support, with pictures and videos. In health care, in order not to draw a hierarchical relationship and indeed realize the need for Exchange and cooperation, there was currently a strong expression of adolescents.

"Water, drinking plenty of water is important to have good health." Adolescent-08, about what is required to have good health.

"Today the Government gives everything, gives condoms." Adolescent-12, about the Government help for prevention of STDs and unplanned/unwanted pregnancy. 
"Crack and cocaine is the same thing that cigarette?" Adolescent-09, asking about the various types of drugs.

"Ah! This was used in the novel to take her (the character) to another place." Adolescent-01, about the use of chloroform.

The lines above show that at this moment the theme work was built in conjunction with the adolescents, ensuring the right to their own participation and ensuring the relevance of their opinion, experiences and questions, adding scientific and empirical knowledge.

About his participation in the group, Adolescent-01 said "the group left the street and had to do more, give examples of things, learn more about things." This address indicates the importance attached by adolescents to their opinion and the appreciation of it; contributing is for learning.

According to Pinafo et al. ${ }^{14}$ health education aims to arouse reflective thinking in front of determined situations to transfer and share knowledge in a playful way, i.e. deconstructing the curative concept that involves only the dissemination of information about pathologies.

Therefore, you must correlate with the experiences of each. Seen in this way, health education becomes a light technology and an effective methodology for the transformation of the current health situation. In this sense, one abandons the pragmatism, since this does not generate experiments, refer to topical actions, without depth and without reflection ${ }^{15}$

It is observed that the thought exposed by the authors above is in line with Baloch et al. ${ }^{16}$ to emphasize in its results the importance of health education as an indicator of quality of life and equity among their peers, in addition to being a service that should be offered to the population that seeks the effective participation of all concerned, from the target audience of the activity tol the governmental spheres.

The participation of adolescents should be treated as interactionist, whereby they feel free to express opinions, make self-criticism and thus enable problem solving in partnership with all those present in the activity ${ }^{17}$. The language adopted for the explanation of the topics has been adapted to the cultural and social reality of the participants and sought the group cohesion, taking account of the needs of adolescents.

There was use of games in a few moments, to approach a greater thematic fixing, knowing that play is a tool that provides self-knowledge and knowledge of the next person through the socialization of experiences in diverse environments, using fantasy and reality, to also integrate people of all ages ${ }^{18}$.

Adolescents, in addition to recreational activities, participated in sharing videos found on the internet with a focus on daily, thematic reporting of experiences with the subject and illustrating situations with facts conveyed by the media, such as newspapers and novels. This can be realized in the following lines
"I can show you a video about anorexia?" Adolescent-02, during the meeting about healthy nutrition and eating disorders.

"Someone there told me that when he used (cocaine) he spent all the night awake, walking around the house. He is my colleague there in the living room." Adolescent-01, during the meeting on licit and illicit drugs.

It is understood that in a continuous process of interaction, listening and opening up to learn about the other enables the shared construction of knowledge and forms of differentiated, appropriate care from this construction ${ }^{19}$.

\section{Participation as a tool for social empowerment}

The "empowerment" of the community, so that it becomes the protagonist of his own history, is the result of processes of social development where the members are recognized as social actors through their participation, this being the fundamental determinant of democracy ${ }^{20}$.

Several are the understandings, and participation is necessary to meet them to commit to such action during periods of health education. For Adolescent-08 "Attending isn't just being present. It is also a stake, but it's also when you have a question you answer." This thought explains that mere presence in a group composes participation but that the process presents a larger number of facets.

Presence is recognized as accession to the group and is critical to the success of it, showing interest in their goals and along with attendance shows that didactic use is ideal, positive, this being a moment of statement and autonomy, where the individual goes on to meet a minimal active and conscious role in the search for ideal health. The relevance is to have the initiative to get involved with programmes and policies, although participation cannot be summed up as the act of being present in a meeting, even if this may have a decision-making effect ${ }^{21}$.

In addition, the interaction constitutes the process of participation. Adolescent-03 states that to say that "Participation is to actively interact with the activities." That participation is required for accession to the group, the approach of relevant issues that interest the members and adoption of a methodology that encourages participation by allowing the members to express themselves and expose their perspectives and concepts. The interaction results in freedom to express yourself and your encouragement, having the bond and communication tools. It cannot be said that there was no participation, i.e. interaction, between the subjects involved ${ }^{22}$.

Adolescent-02 goes a little beyond saying that "Participation is inclusion, integration, courage and interaction". This speaks for the recognition that participation is the result of social inclusion, the exchange with the environment in which they live.

Already Adolescent-07 ensures that to "participate is to be involved in a variety of different activities". It is observed that the interaction and 
involvement with activities are understood as aspects of participation, which makes use of these means to ensure learning and ensure support for positive decisions. There is also the understanding that participation is the result of the act of taking part in any action that one intends to perform ${ }^{23}$.

Recognition of the importance of participation by adolescents was unanimous because:

"It makes us have more attitude about things, have more desire to do things." Adolescent-01.

"You learn when you're participating. "Adolescent-08.

"Participation is good for your knowledge and your self-esteem. "Adolescent-07.

Note that participation is seen by adolescents in their practical application in the face of reality associated with learning, to encourage personal development, the initiative of action, attitude and self-esteem.

The participation in the activities of health education allows the participant to recognize factors influencing health and encourages them to do something to change the status quo ${ }^{4}$. This change of perspective contributes to decision making and consolidation of decisions, making this adolescent a juvenile protagonist, participating in activities that transcend his or her individual interests ${ }^{24}$.

Self-esteem is associated with quality of life, the premise of health promotion, where the individual is satisfied socially and mentally. So participation contributes to the production of aspects and feelings that converge on the state of complete well-being. There is also the association between participation and learning and demonstrating the relationship of dependency between the two, because the greater the learning the greater the participation.

Social inclusion through participation is enhanced by Adolescent-07's speech that says "Join is a form until you are recognized by other people. If you don't participate you may be excluded from certain activities."

Active participation should consider the experience of everyone involved in the process and not treat them as amorphous bodies liable for actions where there is no generation of experience ${ }^{15}$.

During this study the adolescents participated in answering questions, giving opinions and experiences, working within the dynamics and games and contributing materials. During the meeting that treated "healthy nutrition and eating disorders" one adolescent played a video for the group about an adolescent who suffered from anorexia and what reasons led to that situation. The video sparked debate on the topic and broadened participation to other members.

The association of the subjects with the approach of the media was also constant. Novels were the most cited, because they are a representation of reality depicting various conditions and social problems. The thematic comparison with the events of teledramaturgia demonstrates an understanding of the subject and the understanding of its importance as well as its presence in society. This fact is evidenced by mentioning Adolescent-01 who, when questioned if he had already heard about anorexia, replied "I know what anorexia is because I watched the soap opera and the girl had".

Another potential for participation today is the use of social networks that consist of web pages that bring together people with common affinities, such as Facebook, Myspace, Twitter and Banjo. During the planning of the meeting on "healthy nutrition and eating disorders" adolescents made suggestions through one of these social networks on how the subject should be treated, so as to hold the meeting in the best possible way.

Participation must be felt; there must be a sense of empowerment, of training, of action. Adolescent-08 feels he is participating "when I'm paying attention and also answer anything". For Adolescent-01, it feels as if is participating is "when I'm paying attention, doing what the person is sending". One can see a clear process where the individual absorbs information, reflects on it and returns with an answer or experience with your opinion. There is then a debate generating knowledge.

The participation of adolescents through the exchange of experiences and knowledge contributes to the formation of a critical consciousness about the reality in which they are inserted, and so they become autonomous beings able to make satisfactory decisions about their own life, their own family and their own community ${ }^{25}$.

It is this process that defines participation: interaction generating knowledge. The adolescents mentioned the importance of a driver of the process, someone devoid of authoritarianism, who doesn't "impose" but instructs them on the steps of the activities being carried out and coordinates the discussions.

There are desired characteristics for the coordinator of educational processes, in the sense of ethics, the respect, the capacity for synthesis, integration, communication and empathy. ${ }^{11}$ For the realization of these activities, involvement with esteem and pleasure is necessary for the professional participant, emphasizing the commitment to carry out practices that aggrandize public participation and empowerment, and should be seen as the main axis in the practice of these professionals.

Among the skills needed for a satisfactory completion of certain activities, security and accreditation should be broadcast, since the absence of such a feature will not reflect concrete positive results in those who received the information and activities $^{4}$.

Thus, the Bambu Method proved to be an important benchmark for a group meeting and a survey of their needs, allowing for the development of health education activities appropriate to the concerns of its components and thus favouring the participation of these throughout the process. 
Still showed the relevance of the method for Bambu knowledge of reality to be crafted and realization of a group based on empathy, dialogue and the potential of its participants and their community.

Meeting the interfaces of the participatory process in this study allowed an understanding of the various factors involved in order to succeed in the adolescents' actions, allowing critical reflections to redirect the practices of teachers, professionals

\section{REFERENCES}

1. Organização Pan-Americana de Saúde. Carta de Ottawa. Ottawa; 1986.

2. Bydlowski CR, Westphal MF, Pereira IMTB. Promoção da Saúde. Porque sim e porque ainda não!. Saúde Soc. 2004;13(1):14-24.

3. Buss PM. Promoção da Saúde e Qualidade de Vida. Ciênc Saúde Coletiva. 2000;5(1):163177. DOI: http://dx.doi.org/10.1590/S141381232000000100014

4. Machado MFAS, Vieira NFC, Silva RM. Compreensão das mudanças comportamentais do usuário no Programa Saúde da Família por meio da participação habilitadora. Ciênc Saúde Coletiva. 2010;15(4):2133-43. DOI: http://dx. doi.org/10.1590/S1413-812320100004000027

5. Bezerra MAR, Queiroz MVO, Oliveira KNS. Reflexões acerca do adolescer e da saúde no ambiente escolar. J Hum Growth Dev. 2014; 24(2): 175-180. DOI: http://dx.doi.org/10.7322/ jhgd.81036

6. Menezes Filho A, Sá RF, Araújo JÁ, Freire MSM, Salles RS, Chuma J, et al. Manual do método bambu. Núcleo de Saúde Pública e Desenvolvimento Social. Recife: NUSP/UFPE; 2007.

7. Bardin L. Análise de Conteúdo. Lisboa: Edições 70; 2002.

8. Brasil. Ministério da Saúde. Diretrizes nacionais para a atenção integral à saúde de adolescentes e jovens na promoção, proteção e recuperação da saúde. Brasília: Ministério da Saúde; 2010.

9. Brasil. Casa Civil da Presidência da República do Brasil. Lei no 9.394 de 20 de dezembro de 1996. Estabelece as diretrizes e bases da educação nacional. Brasília: 1996.

10. Souza ECF, Vilar RLA, Rocha NSPD, Uchoa AC, Rocha PM. Acesso e acolhimento na atenção básica: uma análise da percepção dos usuários e profissionais de saúde. Cad Saúde Pública. 2009; 24(Suppl 1): S100-S110. DOI: http:/ /dx.doi.org/10.1590/S0102 $311 \times 2008001300015$

11. Dias VP, Silveira DT, Witt RR. Educação em saúde: o trabalho de grupos em atenção primária. Rev APS. 2009;12(2):221-7.

12. Marques JF, Queiroz MVO. Cuidado ao adolescente na Atenção Básica: necessidades dos usuários e sua relação com o serviço. Rev Gaúcha Enferm. 2012; 33(3):65-72. DOI: http://dx. doi.org/10.1590/S1983-14472012000300009

13. Santos CC, Ressel LB. O adolescente no serviço de saúde. Adolesc Saúde. 2013; 1(1): 53-5.

14. Pinafo E, Nunes EFPA, González AD, Garanhani ML. Relações entre concepções e práticas de educação em saúde na visão de uma equipe of the Health of the Family Strategy and other health professionals.

The gradual evolution of participation in the group of adolescents, abandoning the initial shyness and adhering to free expression, the autonomy and freedom of choices can be a result of the acquisition of knowledge and the empowerment of these young people over the meetings, magnified through participation, to be able to make decisions favourable to their health.

de Saúde da Família. Trab Educ Saúde. 2011;9(2):201-21. DOI: http://dx.doi.org/ 10.1590/S1981-77462011000200003

15. Gohn MG. Empoderamento e participação da comunidade em políticas sociais. Saúde Sociedade. 2004; 13(2): 20-31. DOI: http://dx.doi. org/10.1590/S0104-12902004000200003

16. Bezerra IMP, Machado MFAS, Souza OF, Antão JYFL, Dantas MNL, Reis AOA, et al. O fazer de profissionais no contexto da educação em saúde: uma revisão sistemática. J Hum Growth Dev. 2014;24(3):255-62. DOI: http://dx.doi. org/10.7322/jhdg. 88909

17. Pinto MB, Santos NCCB, Albuquerque AM, Ramalho MNA, Torquato IMB. Educação em Saúde para adolescentes de uma escola municipal: a sexualidade em questão. Cienc Cuid Saude. 2013; 12(3): 587-592. DOI: http:// dx.doi.org/10.4025/cienccuidsaude.v12i3. 18470

18. Santos VA, Santos MCV, Cortez FRI. O lúdico no processo de ensino-aprendizagem. Anuário Produção Iniciação Científica Discente. 2011;14(24):289-300.

19. Acioli S. A prática educativa como expressão do cuidado em Saúde Publica. Rev Bras Enferm. 2008;61(1):117-21. DOI: http://dx.doi.org/ 10.1590/S0034-71672008000100019

20. Coelho JS. Construindo a Participação Social no SUS: um constante repensar em busca de equidade e transformação. Saúde Soc. 2012;21(supl.1):138-51.

21. Campos L, Wendhausen A. Participação em saúde: concepções e práticas de trabalhadores de uma equipe da estratégia de saúde da família. Texto Contexto Enferm. 2007; 16(2): 271-9.

22. Brasil. Ministério da Saúde. Saúde do adolescente: competências e habilidades. Brasília: Ministério da Saúde; 2008.

23. Ferreira MA. A educação em saúde na adolescência: grupos de discussão como estratégia de pesquisa e cuidado - educação. Texto Contexto Enferm. 2006;15(2): 205- 211. DOI: http: / / dx.doi.org/10.1590/S010407072006000200003

24. Silva MAI, Mello DF, Carlos DM. O adolescente enquanto protagonista em atividade de educação em saúde no espaço escolar. Rev Elet.Enf. 2010;12(2):287-93.

25. Machado MFAS, Vieira NFC. Educação em saúde: o olhar da equipe de saúde da família e a participação do usuário. Rev Latino-Am. Enferm. 2009;17(2):174-9. DOI: http:// dx.doi.org/10.1590/S0104-11692009000 200006 


\section{Resumo}

Introdução: sabe-se que a adolescência é um período de constantes alterações biopsicossociais, partindo dessa premissa, entende-se que esse público deve ser incluso como prioridade no sistemas de saúde, buscando a sua participação efetiva através de estratégias associadas a promoção da saúde, Objetivo: analisar o processo participativo em atividades de promoção da saúde do adolescente sob a perspectiva do Método Bambu, Método: trata-se de um estudo exploratório qualitativo, realizado em duas escolas da cidade de Crato, CE, Brasil, Participaram alunos com idade entre 10 e 19 anos, O estudo foi baseado no método Bambu que é um meio para impulsionar as potencialidades do grupo, Foram utilizados a observação participante, do ambiente ou das expressões verbais e não-verbais dos adolescentes, e um diário de campo onde foram registradas informações pertinentes, A organização dos dados deu-se mediante a técnica de análise de conteúdo, proposta por Bardin, Resultados: evidenciou-se que a abertura para se expressar junto ao acolhimento levou os jovens a se sentir mais à vontade em meio aos demais, além de induzir a formação do vínculo e configurar o processo participativo, que para os adolescentes foi percebida como um processo voltado para realidade e associada ao aprendizado, ao estímulo para o desenvolvimento pessoal, por meio da iniciativa, da ação, da atitude e da autoestima, Conclusão: o Método Bambu mostrou-se como relevante referencial para guiar ações de educação em saúde com grupos de adolescentes, permitindo a elaboração de atividades adequadas às necessidades dos participantes,

Palavras-chave: adolescente, promoção da saúde, educação em saúde, escola, participação. 